\title{
Caracterization of Liquid Smoke Bamboo Waste with Pyrolysis Method
}

\author{
Warlinda E. Triastuti, Primagita A. Budhi, Elly Agustiani, Rizky A. Hidayat, Rinny Retnoningsih, \\ and Astri A. Nisa'
}

\begin{abstract}
This research was aimed to produce and to analyze the quality and chemical composition of liquid smoke from bamboo waste by pyrolisis process. Temperatur of pyrolisis reactor were $140^{\circ} \mathrm{C}, 180^{\circ} \mathrm{C}, 220^{\circ} \mathrm{C}, 260^{\circ} \mathrm{C}$ and $300^{\circ} \mathrm{C}$ for 5 hours to produce liquid smoke. Liquid smoke purified by filtration, distillation and adsorption. Resulted liquid smoke were analyzed yield, acidity, and density. Identifying the chemical composition of liquid smoke was by Gas Chromatography and Mass Spectrometry (GC-MS). Yield of liquid smoke 1,6977\% up to 3,9713 \%; Acidity of liquid smoke were 1.49 up to 1,9; the density of liquid smoke 1,004 up to 1,045. The results of GC-MS test showed that chemical composition of the liquid smoke have Phenolic compounds 0,5-0,6pm and liquid smoke found not containing of carsinogenic Benz (a) Pyrene.
\end{abstract}

Keywords-Liquid Smoke, Bamboo, Pyrolysis, GC-MS

\section{INTRODUCTION}

Bamboo handicraft products are very popular because of the uniqueness of its products and the trend of the world community to "back to nature", so that the products come from nature are very popular. However, behind the uniqueness of this bamboo handicraft product also generate considerable waste. Bamboo waste from bamboo crafts has not been used optimally so that processing is needed to increase the economic value and useful value. The utilization of bamboo as the primary material of primary and secondary products also has waste that can be utilized as liquid smoke and supply of electrical energy in various ways, including; waste bamboo gasification, bamboo waste briquettes and several other processing systems. Bamboo contains cellulose, hemicellulose, and lignin so it has the potential to serve as liquid smoke. Liquid or pyrolysis or wood vinegar smoke is the result of condensation from wood pyrolysis containing a large number of compounds formed by the process of pyrolysis of wood by using high temperatures with indoor combustion processes (without oxygen) [1]. Liquid smoke is very potential to be used as a biopesticide and as a preservative. Beside that, liquid smoke can be used as biopesticides and food preservatives because they contain acids, phenols and carbon. Liquid smoke has a specific flavor and taste, also has the power to kill against microbes and antioxidant properties that affect the durability of the product [2].

Warlinda E. Triastuti, Primagita A. Budhi, Elly Agustiani, Rizky A. Hidayat, Rinny Retnoningsih, and Astri A. Nisa' are with Department of Industrial Chemical of Engineering, Institut Teknologi Sepuluh Nopember, Surabaya, 60111, Indonesia. E-mail: warlindaeka@chem-eng.its.ac.id.
Liquid smoke is one of the results of plant or wood pyrolysis at a temperature of around $400{ }^{\circ} \mathrm{C}$. Condensation of smoke generated through the pyrolysis reactor chimney will produce liquid smoke. The process of condensation of smoke into liquid smoke is very useful for the protection of air pollution caused by the pyrolysis process. Liquid smoke obtained from the pyrolysis process has the ability to preserve food ingredients because of the presence of acidic compounds, phenolics, and carbonyl [2]. Components of phenol compounds that act as antioxidants in liquid smoke, used as an alternative to replace the function of formalin as a preservative of food that is harmful to health. Liquid smoke can also be applied to the fumigation process so that inconsistent environmental pollution and food quality due to traditional fumigation can be avoided.

The use of liquid smoke has many advantages over traditional fumigation methods, which are easier to apply, faster processing, giving the characteristic characteristics of the final product in the form of more attractive aroma, color, and taste, and its use does not pollute the environment. The content of benzo (a) pyrene in liquid smoke is very low, even according to Guillen, the use of liquid smoke makes it possible to produce smoke products that do not contain benzo (a) pyrene and other carcinogenic compounds.

Research of making liquid smoke from bamboo ever done that make liquid smoke of three types of bamboo that is black bamboo, tutul bamboo and bamboo betung [3]. The results showed that the yield of liquid smoke of three types of bamboo ranged from $5,00-24,00 \%$; $\mathrm{pH} 2.70-3.36$ is in conformity with Japanese standards; specific gravity 0.99 1.03; acetic acid 31,37-83,59\%; methanol $1.37-2.07 \%$ and total phenol $0.56-1.24 \%$. The compounds are able to preserve food so that it can last longer because it has a major function that is as a barrier to bacterial development.

Liquid smoke made from the pyrolysis process of three wood components are cellulose, hemicellulose, and lignin. More than 400 chemical compounds in smoke have been identified. These components are found in varying amounts depending on the type of wood, the age of the wood source plant, and the wood growth conditions such as climate and soil. These components include acids that can affect the taste, $\mathrm{pH}$, and shelf life of fumed products, carbonyls that react with proteins and form brown staining and phenols which are the main formers of aroma and show antioxidant activity.

It is also known that the temperature of making smoke is the factor that determines the quality of smoke produced. The maximum content of phenol, carbonyl and acid compounds was achieved at a pyrolysis temperature of $600{ }^{\circ} \mathrm{C}$. But the 
product given liquid smoke produced at $400{ }^{\circ} \mathrm{C}$ is considered to have the best organoleptic quality compared to liquid smoke produced at higher pyrolysis temperatures.

The groups of constituents of liquid smoke are water (1192\%), phenol (0.2-2.9\%), acid (2.8-9.5\%), carbonyl (2.6$4.0 \%)$ and $\operatorname{tar}(1-7 \%)$. The content of the constituents of liquid smoke greatly determines the organoleptic properties of liquid smoke and determines the quality of fumigation products. The composition and organoleptic properties of liquid smoke depend on the nature of wood, pyrolysis temperature, amount of oxygen, wood moisture, wood particle size and liquid smoke making equipment (Pranata, 2008).

In this research will be made of liquid smoke from bamboo waste by pyrolysis method. And then, impurities of liquid smoke would be adsorb until we get foodgrade liquid smoke.

\section{EXPERIMENTAL SECTION}

\section{A. Materials}

The materials used in this research were Bamboo, active Zeolite, Activated charcoal, Aquadest, Indicator PP.

\section{B. Experimental Methods}

This research procedure begins by drying and cutting bamboo waste. Then put bamboo wastes into the pyrolysis reactor and heated at $140^{\circ} \mathrm{C}, 180^{\circ} \mathrm{C}, 220^{\circ} \mathrm{C}, 260^{\circ} \mathrm{C}$ and $300^{\circ} \mathrm{C}$ for 5 hours. Liquid smoke formed from the pyrolysis proceed to filtration so that liquid smoke separate from tar. The next process was purification, the liquid smoke is distilled and adsorpted. And then the liquid smoke was tested for $\mathrm{pH}$, density and yield. The chemical composition of liquid smoke is tested using GC-MS.

\section{RESULT AND DISCUSSION}

\section{A. Result}

The process of making liquid smoke from bamboo waste by pyrolysis method through three steps of purification such as filtration, distillation and adsorption. Table 1 shows the results of density, $\mathrm{pH}$, total phenol and yield analysis of the resulting liquid smoke.

TABLE 1 .

Results of Testing WITH THE LiQuid SMOKe BAmboo WASTE PYROLYSIS METHOD

\begin{tabular}{ccccc}
\hline \hline $\begin{array}{c}\text { The Pyrolysis } \\
\text { Temperature } \\
\left({ }^{\circ} \mathbf{C}\right)\end{array}$ & $\begin{array}{c}\text { Density } \\
(\mathbf{m g} / \mathbf{m L})\end{array}$ & $\mathbf{p H}$ & $\begin{array}{c}\text { Total } \\
\text { Phenol } \\
(\mathbf{p p m})\end{array}$ & $\begin{array}{c}\text { Yield } \\
(\boldsymbol{\%})\end{array}$ \\
\hline 140 & 1,81 & 1,81 & 0,636 & 1.4664 \\
180 & 1,49 & 1,49 & 0,556 & 0.6890 \\
220 & 1,9 & 1,9 & 0,547 & 0.7067 \\
260 & 1,28 & 1,28 & 0,693 & 0.6360 \\
300 & 1,23 & 1,23 & 0,636 & 3.4141 \\
\hline \hline
\end{tabular}

\section{B. Discussion}

\section{The Liquid Smoke Density Analysis}

The density or specific gravity indicates the number of components present in the liquid smoke which will affect the weight of the liquid smoke. The density of liquid smoke is affected by pyrolysis temperature and purification process. The higher the pyrolysis temperature, the greater the density of liquid smoke. In addition, liquid smoke that has undergone a process of purification, the density value will also increase. The increased time pyrolysis may cause the distillate to come out has been mixed with the tar compound so that the specific gravity of the resulting liquid smoke will increase.

The resulting liquid smoke density shown in Fig. 1. increased at a temperature of $1400^{\circ} \mathrm{C}, 180^{\circ} \mathrm{C}, 220^{\circ} \mathrm{C}, 260^{\circ} \mathrm{C}$ and $300^{\circ} \mathrm{C}$ of $1.0286 \mathrm{gr} / \mathrm{ml} ; 1.0685 \mathrm{gr} / \mathrm{ml} ; 1.0897 \mathrm{gr} / \mathrm{ml}$; $1.1088 \mathrm{gr} / \mathrm{ml}$ and $1.1172 \mathrm{gr} / \mathrm{ml}$. The higher the pyrolysis temperature will be the more cellulose, hemicellulose and lignin in the decomposed and condensed bamboo into liquid smoke containing acetic acid, methanol and phenol so that the density increases.

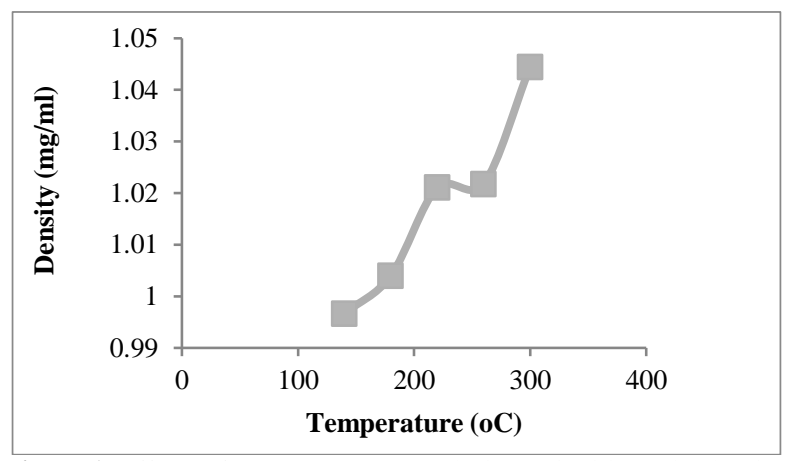

Figure 1. Effects of Temperatures Pyrolysis to Liquid Smoke density.

\section{Analysis of Liquid Smoke $\mathrm{pH}$}

The $\mathrm{pH}$ value is one of the quality parameters of the resulting liquid smoke. The measurement of the $\mathrm{pH}$ value in the resulting smoke aims to determine the level of pyrolysis decomposition process, as well as to produce a natural acid of smoke. If a low $\mathrm{pH}$ value means the smoke produced is of high quality, especially in terms of its use as a food preservative. The low $\mathrm{pH}$ value as a whole has an effect on the durable value and the shelf life of the smoke product or its organoleptic properties. If this $\mathrm{pH}$ value is associated with the total phenol content in the liquid smoke at each treatment, the higher the total phenol content in the liquid smoke the lower the $\mathrm{pH}$ value.

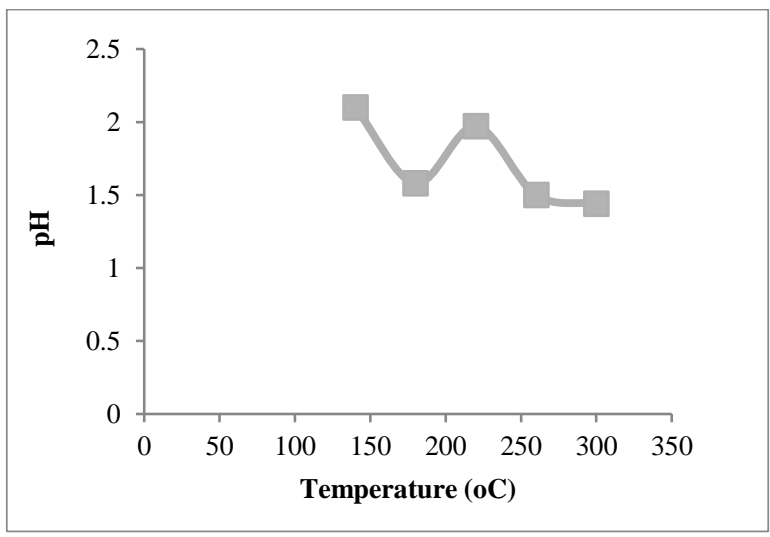

Figure 2. Effects of temperature Pyrolysis to Liquid Smoke pH. 
From Fig.2, shows the decrease of $\mathrm{pH}$ of liquid smoke by increasing pyrolysis temperature. The $\mathrm{pH}$ value of the liquid smoke are as follows, at a temperature of $140{ }^{\circ} \mathrm{C}, 180^{\circ} \mathrm{C}$, $220^{\circ} \mathrm{C}$ and $260^{\circ} \mathrm{C}$, and $300^{\circ} \mathrm{C}$ of $2.1 ; 1.58 ; 1.97 ; 1.5$ and 1.44 $\mathrm{gr} / \mathrm{ml}$. The higher the temperature produced, the more acid is formed so that the $\mathrm{pH}$ of liquid smoke decreases.

\section{Total Phenol Analysis}

Phenol compounds are suspected to act as antioxidants in order to extend the shelf life of the asphalt product the content of phenol compounds in the smoke is highly dependent on the temperature of the wood pyrolysis. The quality of phenol in wood varies considerably between 10 $200 \mathrm{mg} / \mathrm{kg}$. Several types of phenol which are usually present in the smoke product are guaiakol and siringol.

The reactions that occur during pyrolysis are the removal of water from the raw material at a temperature of $120-150^{\circ}$ $\mathrm{C}$, the hemicellulose pyrolysis which produces furfural, furan and its derivatives and a long series of carboxylic acids, acetic acid and homologous at $200-250{ }^{\circ} \mathrm{C}$, cellulose pyrolysis which produces acetic and homologous acids and a small amount of furan and phenol at a temperature of 280 $320^{\circ} \mathrm{C}$, and lignin pyrolysis which produces phenols ethers at $400{ }^{\circ} \mathrm{C}$ [4].

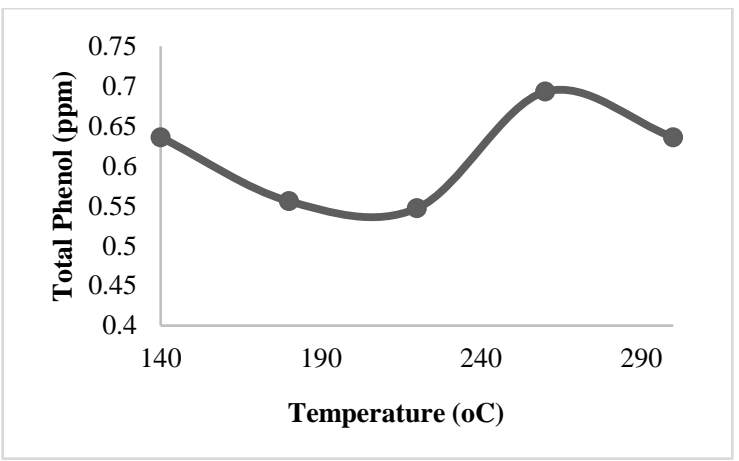

Figure 3. Effects of Temperature Pyrolysis to Total Phenol Liquid Smoke.

From Fig.3 Adsorbtion shows that the graph fluctuates, at a temperature of $140{ }^{\circ} \mathrm{C}, 180{ }^{\circ} \mathrm{C}, 220^{\circ} \mathrm{C}, 260^{\circ} \mathrm{C}$ and $300{ }^{\circ} \mathrm{C}$ of $0.636 ; 0.556 ; 0.547 ; 0.693$ and 0.636 . This is by the characteristics of bamboo used.

\section{Liquid Smoke Yield Analysis}

The amount of liquid smoke produced in the pyrolysis process depends on the type of raw material used. The percentage of yield obtained also depends on the condensation system used. This condition is in accordance with the founded Tranggono [5], that for the formation of liquid smoke water is used as a cooling medium for the heat exchange process can occur quickly [5]. Pyrolysis at too high a temperature and too long will cause the formation of liquid smoke to decrease as the temperature in the cooling water increases so that the smoke produced is not completely condensed. The condensation process will take place optimally if the water in the cooling system is continuously fluids increase so that the temperature in the system does not increase. This is in accordance with the statement of
Demirbas that the liquid smoke from the wood pyrolysis process can be produced maximum if the condensation process is complete.

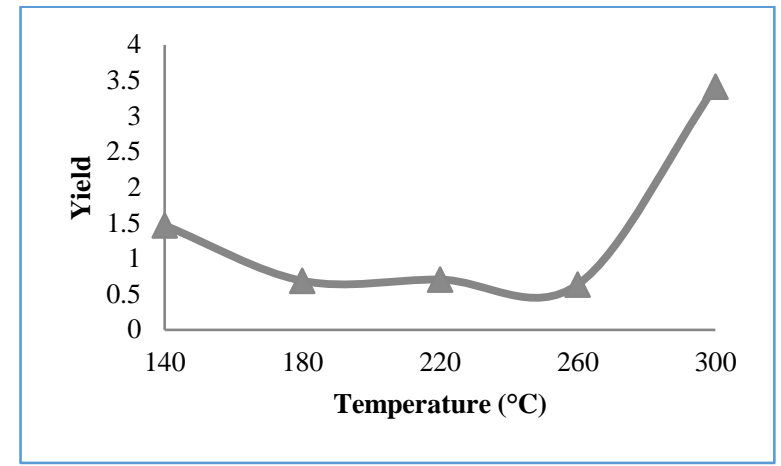

Figure 4. Effects of Temperature Pyrolysis with Liquid Smoke Yield

From Fig. 4 occurs a decrease of yield of $140{ }^{\circ} \mathrm{C}, 180^{\circ} \mathrm{C}$, $220{ }^{\circ} \mathrm{C}$ and $260{ }^{\circ} \mathrm{C}$, of $1.47 ; 0.68 ; 0.71 ; 0.64$, while at a temperature of $300{ }^{\circ} \mathrm{C}$ increased to 3.41. The decrease of liquid smoke yield is caused by a less than perfect condensation system because the cooling water flow in the condenser does not flow continuously, while at $300{ }^{\circ} \mathrm{C}$ the cooling water in the condenser is changed so that the liquid smoke yield increases. Theoretically, the rising temperatures also increase the yield of liquid smoke as more cellulose, hemicellulose and lignin in decomposed and condensed bamboo into liquid smoke.

5. GC-MS Analysis

The GC-MS analysis was performed to determine the types of compounds present in liquid smoke. GC-MS liquid smoke results show that there are 87 compounds and no benzo (a) pyene in liquid smoke produced in liquid smoke manufacture with pyrolysis temperature $300^{\circ} \mathrm{C}$.

Distillation process is one way of purification of liquid smoke, which is the process of separating a solution based on its boiling point [4][1]. The distillation of liquid smoke is carried out to remove harmful compounds such as polycyclic aromatic hydrocarbons (PAHs) and tar. Benzo (a) pyren has a high boiling point that is $312^{\circ} \mathrm{C}$ so that when distillation process with a temperature of $150^{\circ} \mathrm{C}-200^{\circ} \mathrm{C}$ benzo (a) pyrene is not vaporized and left in the distillate flask.

The results of this analysis indicate that one of the expected objectives of this study is to reduce the health risk for humans due to the content of carcinogen compounds so that the liquid smoke that is foodgrade has been fulfilled because it is not found benzo (a) pyent in liquid smoke.

\section{CONCLUSION}

From the research can be concluded that the liquid smoke produced by the pyrolysis method with filtration, distillation and adsorbtion has a yield of $1.6977 \%-3.9713 \%$; $\mathrm{pH} 1.49$ 1.9; and density of $1.004-1.045$. The results of the GC-MS test shows the chemical composition of liquid smoke with a total of 0.5 to $0.6 \mathrm{ppm}$ phenol and no benz (a) Pyrene carcinogenic compound was found 
International Conference on Engineering, Advance Science and Industrial Application (ICETESIA) 2018

September 6-7 2018, Institut Teknologi Sepuluh Nopember, Surabaya, Indonesia

\section{ACKNOWLEDGMENT}

We gratefully acknowledgement the authors would like to thank LPPM ITS on the Hibah Penelitian Pemula 2016.

\section{REFERENCES}

[1] H. Oramahia and F. Diba, "Maximizing the Production of Liquid Smoke from Bark of Durio by Studying Its Potential Compounds," Procedia Environ. Sci., vol. 17, pp. 60-69, 2013.

[2] M. Wijaya, E. Noor, T. T. Irawadi, and G. Pari, "Characterization of the chemical component of Liquid smoke and its utulization as biofestiside," Bionature, vol. 9, no. 1, pp. 34-40, 2008.

$[3]$

K. Sri and W. Santiyo, "Characteristics of Liquid Smoke from Three Types of Bambo," J. For. Prod. Res., vol. 33, no. 2, pp. 167-174, 2012.

[4] Darmaji, "Optimization of Smoke-making Process," Agritechl, vol. 22 , no. 4,2000 .

[5] S. Tranggono and B. Setiadji, "Produksi Asap Cair dan Penggunaannya pada Pengolahan Beberapa Bahan Makanan Khas Indonesia," 1997. 